\title{
Efek Imunomodulator Ekstrak Etanol Spons Melophlus sarasinorum Terhadap Aktivitas Fagositosis Sel Makrofag Pada Mencit Jantan Balb/C
}

\section{(Immunomodulatory Effects of Ethanol Extract of Melophlus sarasinorum Sponge Against Phagocytosis Activity of Macrophage Cells on Balb/C Male Mice)}

\author{
Wahyuni $^{1}$, Muhammad Ilyas Yusuf ${ }^{1,2 *}$, Fadhliyah Malik ${ }^{1}$, Adryan Fristiohady Lubis ${ }^{1}$, Astrid \\ Indalifiany ${ }^{1}$, I Sahidin ${ }^{1}$ \\ ${ }^{1}$ Jurusan Farmasi Fakultas Farmasi Universitas Halu Oleo, Kendari, Jl. H.E.A Mokodompit Kampus Hijau \\ Bumi Tridharma, Kendari, Sulawesi Tenggara, 93132 \\ ${ }^{2}$ Politeknik Bina Husada Kendari, Jl. Sorumba No.17 Kendari-Sulawesi Tenggara, 93117
}

Article Info:

Received: 07 September 2019

in revised form: 23 September 2019

Accepted: 3 October 2019

Available Online: 9 October 2019

Keywords:

Sponge

Melophlus sarasinorum

Extract

Macrophage

Immunomodulator

Corresponding Author:

Muhammad Ilyas Yusuf

Jurusan Farmasi

Fakultas Farmasi

Universitas Halu Oleo

Kendari, Sulawesi Tenggara

Indonesia

93132

email :

ilyasyusufmuhammad.apt@gmail.com

\begin{abstract}
Immunomodulator is an ingredient or drug that can modulate immune system functions and activities. This study was conducted to determine the effect of ethanol extract of Melophlus sarasinorum sponge on macrophage phagocytosis activity. Twenty four male mice balb/c were divided into six groups. The first group received $100 \mathrm{mg} / \mathrm{kg}$ of ethanol extract of Melophlus Sarasinorum sponge, the second group received $200 \mathrm{mg} / \mathrm{kg}$ of ethanol extract of Melophlus sarasinorum sponge, the third group received 300 $\mathrm{mg} / \mathrm{kg}$ of ethanol extract of Melophlus Sarasinorum sponge and the fourth group received $400 \mathrm{mg} / \mathrm{kg}$ of ethanol extract of Melophlus Sarasinorum sponge. The positive control group received Phyllanthus niruri linn extract $\left(\right.$ Stimuno ${ }^{\circledR}$ ) $0,13 \mathrm{mg} / \mathrm{g}$ and the negative control group received NaCMC $0,5 \%$. The extract was orally administered from first day to seventh day. On the eighth day, each of the mice was injected Staphylococcus aureus bacteria (SA) $0.5 \mathrm{~mL}$ intraperitoneally. Macrophage cell activity is calculated from smears of peritoneal fluid of mice. Increased doses of ethanol extract of Melophlus sarasinorum sponge increase the amount of macrophage phagocytosis activity that are 25,25\% (negative control), 61,5\% (positive control), 55,75\% (100 mg/kg), 60,75\% (200 mg/kg), $62,25 \%$ (300 mg/kg) dan 66,25\% (400 mg/kg). The results showed that the ethanol extract of Melophlus sarasinorum sponge has the potential as immunomodulator at a doses of $300 \mathrm{mg} / \mathrm{kgBB}$ and $400 \mathrm{mg} / \mathrm{kg}$ with no significantly different effectiveness with positive control in increasing macrophage cell phagocytosis activity based on the result of post-hoc statistical test of Tukey (sig.> 0,05).
\end{abstract}

How to cite (APA 6th Style):

Wahyuni., Yusuf. M. I., Malik. F., Lubis. A. F., Indalifiany. A., Sahidin. I., (2019). Efek Imunomodulator Ekstrak Etanol Spons Melophlus sarasinorum Terhadap Aktivitas Fagositosis Sel Makrofag Pada Mencit Jantan Balb/C. Jurnal Farmasi Galenika :Galenika Journal of Pharmacy, 5(2), 147-157. doi:10.22487/j24428744.2019.v5.i2.13611 


\begin{abstract}
ABSTRAK
Imunomodulator adalah suatu bahan atau obat yang dapat memodulasi fungsi dan aktivitas sistem imun. Penelitian ini dilakukan untuk mengetahui pengaruh pemberian ekstrak etanol spons Melophlus sarasinorum terhadap aktivitas fagositosis makrofag pada mencit galur Balb/C. Sebanyak dua puluh empat ekor mencit jantan galur Balb/c dibagi ke dalam 6 kelompok. Kelompok kontrol negatif diberi NaCMC 0,5\%. Kelompok kontrol positif diberi ekstrak Phyllanthus niruri Linn. (Stimuno ${ }^{\circledR}$ ) 0,13 $\mathrm{mg} / \mathrm{gBB}$, dan masing-masing kelompok dosis diberi perlakuan dengan memberikan dosis ekstrak etanol spons Melophlus sarasinorum sebanyak $100 \mathrm{mg} / \mathrm{kgBB}, 200 \mathrm{mg} / \mathrm{kgBB}, 300 \mathrm{mg} / \mathrm{kgBB}$, dan 400 mg/kgBB. Ekstrak diberikan secara peroral sejak hari pertama hingga ketujuh. Pada hari kedelapan masing-masing mencit diinjeksikan bakteri Staphylococcus aureus (SA) 0,5 mL secara intraperitoneal lalu dibedah dan diambil cairan peritoneum. Selanjutnya diamati sel makrofag dibawah mikroskop cahaya dengan perbesaran 400X dan 1000X. Hasil persentase aktivitas fagositosis makrofag pada kontrol negatif yakni sebesar 25,25\%; kelompok kontrol positif 61,5\%; kelompok dosis $100 \mathrm{mg} / \mathrm{kgBB}$ 55,75\%, kelompok dosis $200 \mathrm{mg} / \mathrm{kgBB}$ 60,75\%, kelompok dosis $300 \mathrm{mg} / \mathrm{kgBB}$ 62,25\%, dan kelompok dosis 300 mg/kgBB 66,25\%. Data hasil pengujian dianalisis secara statistik dengan metode post hoc Tukey dan menunjukkan hasil bahwa ekstrak etanol spons Melophlus sarasinorum memiliki potensi sebagai imunomodulator pada dosis $200 \mathrm{mg} / \mathrm{kgBB}$, $300 \mathrm{mg} / \mathrm{kgBB}$, dan $400 \mathrm{mg} / \mathrm{kgBB}$ dengan efektivitas yang tidak berbeda nyata dengan kontrol positif $\left(\right.$ Stimuno $^{\circledR}$ ) dalam meningkatkan aktivitas fagositosis sel makrofag.
\end{abstract}

Kata kunci: Spons, Melophlus sarasinorum, Ekstrak, Makrofag, Imunomodulator

\section{PENDAHULUAN}

Sistem imun merupakan sistem yang bertanggung jawab melindungi tubuh dari benda-benda asing yang masuk sehingga fungsi tubuh tidak terganggu (Aldi, et al., 2015). Sistem imunitas memiliki fungsi membantu perbaikan DNA manusia, mencegah infeksi yang disebabkan oleh jamur, bakteri, virus, dan organisme lain, serta menghasilkan antibodi (imunoglobulin) untuk memerangi serangan bakteri dan virus asing ke dalam tubuh (Aspinall, 2005). Sistem imun non spesifik merupakan pertahanan pertama terhadap mikroorganisme atau benda-benda asing yang masuk dalam tubuh (Abbas, et al., 2007). Salah satu upaya yang dilakukan sistem imun non spesifik dalam mempertahankan diri terhadap masuknya antigen yaitu dengan cara menghancurkan antigen melalui proses fagositosis. Proses fagositosis yang efektif pada invasi mikroorganisme dini dapat mencegah timbulnya penyakit (Kresno, 1996).

Fagositosis antigen dapat dilakukan oleh beberapa sel antara lain sel makrofag. Makrofag tersebar secara luas dalam tubuh manusia serta berperan dalam proses peradangan sebagai reaksi tubuh terhadap benda asing atau mikroba. Salah satu peran utama makrofag dalam sistem imunitas alami adalah fungsi fagositosis. Makrofag memfagositosis patogen, selsel mati dan beberapa komponen dalam matriks ekstraselular (Christina, 2015). Salah satu upaya untuk meningkatkan aktivitas fagositosis makrofag yaitu dengan zat-zat yang bersifat imunomodulator (Akrom et al., 2015). Penelitian sebelumnya yang telah dilakukan Yusuf et al., (2019) menunjukkan adanya pengaruh pemberian ekstrak daun galing terhadap aktivitas fagositosis makrofag. Hal ini dikarenakan adanya senyawa yang semakin memudahkan sel fagosit untuk melakukan fungsinya dalam memfagositosis antigen karena adanya fungsi opsonin. Opsonin adalah zat yang berfungsi meningkatkan aktivitas fagositosis (Pangestika et al., 2012)

Imunomodulator adalah senyawa yang dapat mengembalikan ketidakseimbangan sistem imun. Cara kerja imunomodulator adalah mengembalikan fungsi sistem imun yang terganggu (imunorestorasi), meningkatkan fungsi sistem imun (imunostimulan) dan menekan respon imun (imunosupresi). Imunomodulator digunakan terutama pada penyakit 
imunodefisiensi, infeksi kronis, dan infeksi (Katzung et al., 1995). Akan tetapi penggunaan imunomodulator dalam terapi kadang kala mengalami hambatan. Diantara hambatan yang sering kali muncul adalah harga yang kurang terjangkau, obat yang tersedia di pasar dalam bentuk paten, dan mayoritas diimpor dari luar negeri. Dalam keadaan demikian, sangatlah perlu dipertimbangkan untuk memperoleh imunomodulator dari bahan alam agar faktor harga dapat ditekan (Yusuf et. al., 2019).

Senyawa-senyawa yang dapat memodulasi sistem imun salah satunya dapat diperoleh dari spons. Hal ini dikarenakan spons merupakan salah satu komponen ekosistem terumbu karang yang sangat potensial sebagai sumber bahan aktif. Hal ini dapat terjadi karena biosintesis senyawa aktif spons sangat dipengaruhi oleh perubahan bioekologinya sebagai respon pertahanan sistem metabolisme sel dari gangguan organisme lain disekitarnya (Reha et al., 2013). Melophlus sarasinorum merupakan salah satu jenis spons yang banyak terdapat di daerah perairan Sulawesi Tenggara.

Penelitian yang dilakukan oleh Soekamto et al., 2013, menunjukkan bahwa spons Melophlus sarasinorum mengandung metabolit sekunder seperti steroid, alkaloid, fenolik, flavanoid, dan saponin. Sementara itu, penelitian lain yang dilakukan oleh Hardianti (2018) juga menunjukkan bahwa spons Melophlus sarasinorum mengandung metabolit sekunder alkaloid, flavanoid, tanin, dan saponin. Senyawa flavonoid dan saponin, berdasarkan uji secara in vitro telah menunjukkan adanya respon imun. Efek terhadap respon imun non spesifik berupa peningkatan fagositosis dan kemotaksis makrofag, kemotaksis neutrofil, sitotoksisitas sel NK serta aktivitas hemolisis komplemen (Kurnianingtyas et al., 2013).

\section{METODE PENELITIAN}

\section{Alat dan Bahan}

Alat-alat yang digunakan adalah rotary evaporator $\left(\right.$ Buchi $\left.^{\circledR}\right)$, autoklaf, blender (Philips $\left.{ }^{\circledR}\right)$, erlenmeyer $\left(\right.$ Pyrex $\left.^{\circledR}\right)$, timbangan analitik $\left(\right.$ Precisa $\left.{ }^{\circledR}\right)$, gelas ukur $\left(\right.$ Pyrex $^{\circledR}$ ), gelas kimia (Pyrex $\left.{ }^{\circledR}\right)$, oven (Gallenkamp Civilab-Australia), inkubator, botol vial, neraca analitik (Stuart $\left.{ }^{\circledR}\right)$, laminar air flow (LAF), bunsen, pipet tetes, pipet ukur, tabung reaksi, batang pengaduk, kertas saring, botol gelap, toples, cawan porselin, kaca objek, kaca preparat, mikroskop elektrik, stirrer, pinset dan pisau bedah, elektromantel, ose bulat, spoit, kandang mencit.

Bahan-bahan yang digunakan pada penelitian ini adalah spons Melophlus sarasinorum, mencit jantan galur BALB/C, bakteri Staphylococcus aureus yang diperoleh dari Laboratorium Farmasi Fakultas Farmasi Universtas Halu Oleo, kapas, tissu, aluminium foil, etanol 96\%, alkohol 70\%, methanol, akuades, Na-CMC $0,5 \%, \mathrm{NaCl}$ fisiologis, phosphate buffered saline PH 7,8 (PBS), eter, pewarna giemsa, minyak emersi, nutrient agar (NA), dan ekstrak meniran komersional (Stimuno ${ }^{\circledR}{ }^{\circledR}$ ). Subjek penelitian ini adalah mencit galur balb/c jantan dengan berat badan 20-30 gram pada usia 10 minggu dan dalam keadaan sehat. Pemilihan galur balb/c karena galur ini pada umur 6-12 minggu telah dilaporkan dapat menimbulkan respon imun selluler apabila mencit diinduksi dengan bakteri Staphylococcus aureus.

\section{Prosedur Penelitian}

\section{Pengambilan dan Preparasi Sampel}

Sampel spons sebanyak 1,8 Kg diperoleh dari Taman Pendidikan laut Bintang Samudra di Kelurahan Sawa Pudo, Kecamatan Soropia, Kabupaten Konawe, Provinsi Sulawesi Tenggara. Pengambilan sampel dilakukan dengan menggunakan pisau dan cutter dengan peralatan selam SCUBA (Self Contained Underwater Breathing Apparatus). Sampel spons dikumpulkan di dalam box ice dan dibiarkan semalaman dalam keadaan tetap dingin, dilakukan sortasi basah, dibersihkan dari hewan laut yang hidup di dalam spons dengan cara dicuci dengan air mengalir, kemudian dipotong menjadi ukuran yang lebih kecil, kemudian dilanjutkan dengan melakukan proses ekstraksi.

\section{Determinasi sampel}

Sampel yang digunakan pada penelitian ini pertamatama dilakukan determinasi untuk memastikan bahwa spons merupakan sampel yang dimaksud, bukan spons lain. Determinasi spons dilakukan di Laboratorium Fakultas Perikanan Universitas Halu Oleo.

\section{Ekstraksi}

Metode ekstraksi yang digunakan yaitu metode maserasi. Sebanyak 3,6 kg potongan kecil spons Melophlus sarasinorum dimasukkan ke dalam wadah tertutup dan direndam dengan menggunakan pelarut 
etanol 96\% selama 3 x 24 jam. Hasil maserasi kemudian disaring. Filtrat yang diperoleh dari hasil penyaringan kemudian dipekatkan dengan penguapan berputar menggunakan rotary vacum evaporator pada suhu $40^{\circ} \mathrm{C}$ hingga diperoleh ekstrak kental. Ekstrak ditimbang untuk mengetahui bobotnya.

\section{Skrining Kimia}

Komponen yang terdapat dalam spons Melophlus sarasinorum dianalisis golongan senyawa dengan tes uji tabung dengan menggunakan beberapa pereaksi untuk golongan senyawa alkaloid, flavonoid, saponin, tanin, dan terpenoid. Skrining fitokimia pada penelitian ini dilakukan untuk mengetahui senyawa kimia yang terdapat di dalam ekstrak etanol spons Melophlus sarasinorum.

\section{Karakterisitik Ekstrak}

Karekterisasi yang dilakukan dalam penelitian ini meliputi parameter spesifik ekstrak dengan pemeriksaan organoleptik, penetapan kadar air, kadar abu total, kadar sari larut air, dan kadar sari larut etanol. Karakterisasi ini dilakukan dengan tujuan untuk menjamin keseragaman mutu ekstrak agar memenuhi persyaratan standar ekstrak.

\section{Pengujian Aktivitas Fagositosis Sel Makrofag}

\section{Penyiapan Suspensi Bakteri Uji}

Bakteri uji pada media agar miring diambil dengan kawat ose steril lalu disuspensikan ke dalam tabung yang berisi $2 \mathrm{~mL}$ larutan $\mathrm{NaCl}$ 0,9 \% hingga diperoleh kekeruhan yang sama dengan standar kekeruhan larutan Mc. Farland (ngajow, 2013). Kekeruhan bakteri diukur sesuai dengan standar Mc Farlan 0,5 menggunakan spektrrofotometer 20 D pada panjang gelombang $625 \mathrm{~nm}$. Larutan Mc Farlan dibuat dengan komposisi 0,05 $\mathrm{mL} \mathrm{BaCl}_{2} 1 \%$ dan 9,95 $\mathrm{mL} \mathrm{H}_{2} \mathrm{SO}_{4}$ (Ginting, 2012; Assidqi et al., 2012).

\section{Uji Fagositosis}

Perlakuan hewan uji dilakukan setiap 1 hari sekali selama 7 hari secara peroral sesuai dengan volume pemberian. Kelompok I, mencit diberikan ekstrak dosis $100 \mathrm{mg} / \mathrm{kgBB}$. Kelompok II, mencit diberikan ekstrak dosis $200 \mathrm{mg} / \mathrm{kgBB}$. Kelompok III, mencit diberikan ekstrak dosis 300 mg/kgBB. Kelompok IV, mencit diberikan ekstrak dosis $400 \mathrm{mg} / \mathrm{kgBB}$, kelompok $\mathrm{V}$ sebagai kontrol positif diberikan Stimuno $^{\circledR}$ yang mengandung ekstrak meniran komersial dosis 0,13 mg/kgBB dan kelompok VI sebagai kontrol negatif yang diberikan Na-CMC 0,5\%. Pada hari ke delapan setiap mencit diinfeksi dengan $0,5 \mathrm{~mL}$ suspensi bakteri SA secara intraperitoneal, dibiarkan selama satu jam. Mencit dianastesi dengan eter lalu dibedah perutnya dengan menggunakan gunting bedah dan pinset steril. Jika ditemukan cairan peritoneum dalam jumlah sedikit pada perut, maka ditambahkan larutan Phosphat buffered saline (PBS) pH 7,8 steril sebanyak 1-2 mL, digoyang-goyangkan secara perlahan kemudian diambil cairan peritoneum dengan spoit 1 cc. Cairan peritoneal dipulas pada gelas obyek dan difiksasi dengan metanol selama 5 menit, kemudian diwarnai dengan pewarnaan Giemsa 10\%, didiamkan 20 menit, dibilas dengan air mengalir. Setelah sediaan kering, dilihat di bawah mikroskop menggunakan minyak emersi dengan perbesaran (10x-1000x) (Nugroho, 2012).

\section{Menghitung Aktivitas Fagositosis}

Aktivitas imunostimulan ditentukan dengan menghitung aktivitas fagositosis sel makrofag peritonium mencit. Nilai aktivitas fagositosis adalah persentase sel makrofag yang aktif melakukan proses fagositosis di antara 100 sel makrofag (Masurin dan Chairul, 2012)

$\%$ Aktivitas fagositosis $=\frac{\text { jumla } h \text { sel makrofag aktif }}{\text { jumla h sel makrofag teramati }} \times 100 \%$

\section{Analisis Data}

Metode analisis data yang digunakan dalam penelitian ini yaitu metode Analysis of Variance (ANOVA) one-way dengan syarat terdistribusi normal, taraf kepercayaan 95\% $(\alpha=0,05)$. Analisis data dilanjutkan dengan analisis post hoc Tukey menggunakan aplikasi statistical product and service solution (SPSS) versi 21.0 for windows 8 .

\section{HASIL DAN PEMBAHASAN}

\section{Determinasi Sampel}

Determinasi spons Melophlus sarasinorum dilakukan dengan tujuan untuk menghindari kemungkinan terjadinya kesalahan dalam pengambilan sampel yang akan digunakan pada uji aktivitas fagositosis 
makrofag. Hal tersebut dilakukan dengan memperhatikan ciri-ciri morfologi yang ada dalam spons Melophlus sarasinorum dengan menggunakan petunjuk pustaka dan dibuktikan di Laboratorium Fakultas Perikanan. Hasil determinasi menunjukkan bahwa spons yang diteliti adalah spons jenis Melophlus sarasinorum.

\section{Ekstrak}

Ekstrak kental spons Melophlus sarasinorum yang didapatkan seberat 27,35 gram dengan nilai rendamen $1,5 \%$.

\section{Skrining Kimia}

Komponen yang terdapat dalam spons Melophlus sarasinorum dianalisis golongan senyawa dengan tes uji tabung dengan menggunakan beberapa pereaksi untuk golongan senyawa alkaloid, flavonoid, saponin, tanin, dan terpenoid. Skrining fitokimia pada penelitian ini dilakukan untuk mengetahui senyawa kimia yang terdapat di dalam ekstrak etanol spons Melophlus sarasinorum. Hasil skrining fitokimia disajikan pada tabel 1.

Tabel 1. Hasil skrining fitokimia spons Melophlus sarasinorum

\begin{tabular}{|c|c|c|c|}
\hline No & $\begin{array}{c}\text { Komponen } \\
\text { Senyawa }\end{array}$ & Hasil Identifikasi & Keterangan \\
\hline 1 & Alkaloid & $\begin{array}{c}\text { Terbentuk endapan } \\
\text { coklat }\end{array}$ & + \\
\hline 2 & Flavonoid & $\begin{array}{c}\text { Terjadi perubahan } \\
\text { warna menjadi } \\
\text { merah }\end{array}$ & + \\
\hline 3 & Saponin & $\begin{array}{l}\text { Terbentuk busa } \\
\text { yang stabil. }\end{array}$ & + \\
\hline 4 & Tanin & $\begin{array}{l}\text { Terbentuk warna } \\
\text { hijau kehitaman }\end{array}$ & + \\
\hline 5 & Terpenoid & $\begin{array}{l}\text { Tidak Perubahan } \\
\text { warna menjadi } \\
\text { coklat }\end{array}$ & + \\
\hline
\end{tabular}

\section{Karakterisasi Ekstrak}

Karekterisasi yang dilakukan dalam penelitian ini meliputi parameter spesifik ekstrak dengan pemeriksaan organoleptik, penetapan kadar air, kadar abu total, kadar sari larut air, dan kadar sari larut etanol. Karakterisasi ini dilakukan dengan tujuan untuk menjamin keseragaman mutu ekstrak agar memenuhi persyaratan standar ekstrak. Hasil karakterisasi dapat dilihat pada tabel 2.
Tabel 2. Hasil karakterisasi ekstrak

\begin{tabular}{ll}
\hline \multicolumn{1}{c}{ Jenis karakterisasi } & Hasil \\
\hline Organoleptis: & \\
Bentuk & Kental \\
Warna & Merah tua \\
Bau & Khas \\
Kadar air & $5,64 \%$ \\
Kadar abu & $7,24 \%$ \\
Kadar sari larut etanol & $61,075 \%$ \\
Kadar sari larut air & $40,27 \%$ \\
\hline
\end{tabular}

Pemeriksaan organoleptik ekstrak yang meliputi bentuk, warna, dan bau diperoleh hasil ekstrak yaitu berkonsistensi kental, berwarna merah tua dan berbau khas. Penentuan parameter organoleptik ekstrak ini bertujuan untuk memberikan pengenalan awal ekstrak secara objektif dan sederhana yang dilakukan dengan menggunakan panca indera (Angelina, et,al., 2015).

Penetapan kadar air ekstrak sangat penting untuk memberikan batasan maksimal kandungan air di dalam ekstrak, karena jumlah air yang tinggi dapat menjadi media tumbuhnya bakteri dan jamur yang dapat merusak senyawa yang terkandung di dalam ekstrak (Depkes RI, 2000). Persyaratan kadar air ekstrak menurut parameter standar yang berlaku adalah tidak lebih dari $10 \%$. Kadar air pada spons Melophlus sarasinorum adalah 5,64\%. Kadar air ekstrak sudah memenuhi persyaratan yaitu kadar air ekstrak tidak boleh melebihi 10\% (Ditjen POM, 2008).

Penetapan kadar abu dilakukan dengan tujuan untuk memberikan gambaran kandungan mineral internal dan eksternal yang berasal dari proses awal sampai terbentuknya ekstrak. Menurut Farmakope herbal I kadar abu tidak lebih dari 7\%. Kadar abu berkaitan dengan mineral baik senyawa garam organik maupun garam anorganik yang diperoleh secara internal maupun eksternal (Depkes RI, 2000). Kadar abu spons Melophlus sarasinorum adalah 7,24\%. Hal ini menunjukkan bahwa sisa unsur anorganik dalam ekstrak sebesar 7,24\%. Senyawa yang termasuk garam anorganik antara lain dalam bentuk garam fosfat, karbonat, khlorida, sulfat, dan nitrat (Sudarmadji, 1989). Unsur mineral dikenal sebagai zat organik atau kadar abu. Dalam proses pembakaran, bahan-bahan oragnik terbakar tetapi zat 
anorganiknya tidak, karena itulah disebut abu (Winarno, 1992). Tingginya kadar garam klorida yang terdapat dalam esktrak dapat menjadi salah satu faktor tingginya kadar abu pada esktrak. Sehingga kedepannya diperlukan proses ekstraksi yang dapat mengurangi kadar garam klorida yang ada pada ekstrak.

Penetapan kadar sari larut air dan etanol dilakukan untuk memberikan gambaran awal jumlah senyawa yang dapat tersari dengan pelarut air dan etanol dari suatu ekstrak (Depkes RI, 2000). Dari hasil pengujian menunjukkan kadar sari larut air spons Melophlus sarasinorum memiliki nilai 40,27 \%, sedangkan kadar sari larut etanol sebesar 61,075\%. Hal ini menunjukkan bahwa jumlah senyawa polar yang dapat terlarut dalam air, lebih kecil daripada jumlah senyawa kurang polar (semi polar maupun non polar) yang dapat terlarut dalam etanol. Kadar sari larut air dan etanol juga menunjukkan senyawa kimia yang diduga berperan dalam menentukan efek farmakologi. Semakin tinggi persentase kadar sari maka semakin baik ekstrak tersebut (Isnawati, 2013).

\section{Uji Efek Imunomodulator}

Pengujian efek imunomodulator pada penelitian ini dilakukan untuk mengetahui efek imunomodulator ekstrak spons Melophlus sarasinorum terhadap peningkatan aktivitas fagositosis makrofag mencit jantan. Ekstrak etanol spons Melophlus sarasinorum divariasikan menjadi 4 dosis, yaitu dosis I 100 $\mathrm{mg} / \mathrm{kgBB}$, dosis II $200 \mathrm{mg} / \mathrm{kgBB}$, dosis III 300 $\mathrm{mg} / \mathrm{kgBB}$, dan dosis IV $400 \mathrm{mg} / \mathrm{kgBB}$. Variasi dosis bertujuan untuk mengetahui pada dosis berapa ekstrak etanol spons Melophlus sarasinorum memiliki aktivitas sebagai imunomodulator. Kontrol positif yang digunakan adalah Stimuno ${ }^{\circledR}$ dosis $50 \mathrm{mg}$ (kelompok V) sedangkan kontrol negatif $\mathrm{Na}-\mathrm{CMC}$ (kelompok VI). Pemilihan Stimuno ${ }^{\circledR}$ sebagai kontrol positif sesuai penelitian yang dilakukan oleh Yusuf et. al., (2019) dimana Stimuno ${ }^{\circledR}$ yang mengandung ekstrak meniran terbukti sebagai imunomodulator, dengan cara memberikan rangsangan kepada reseptor sel imun serta mengirimkan sinyal intra seluler pada reseptor sel sehingga dapat meningkatkan kerja sel imun lebih baik (Febriana, 2015). Sedangkan kontrol negatif yang digunakan adalah Na-CMC 0,5\%. Pemilihan Na-CMC sebagai kontrol negatif karena Na-CMC tidak mengandung zat aktif sehingga tidak dapat memberikan efek farmakologi apapun pada hewan uji. Na-CMC pada penelitian ini juga digunakan sebagai pensuspensi dalam sediaan yang dibuat, karena Na-CMC mempunyai sifat yang inert serta menghasilkan suspensi yang stabil.

Masing-masing kelompok hewan uji diberikan perlakukan dosis ekstrak selama 7 hari berturut-turut secara peroral sebanyak satu kali sehari dengan tujuan untuk menstimulasi sistem imun dari masingmasing kelompok hewan uji. Hingga hari kedelapan setiap mencit pada masing-masing kelompok diinfeksi dengan $0,5 \mathrm{~mL}$ suspensi bakteri $S$. aureus secara intraperitoneal. Staphylococcus aureus digunakan karena merupakan bakteri gram positif. Jenis bakteri gram positif ini mampu mengikat warna giemsa dengan jelas sehingga memudahkan dalam perhitungan di bawah mikroskop. Bakteri ini juga tidak mengandung protein $\mathrm{A}$, yaitu protein yang bersifat antifagositik sehingga $S$. aureus tidak dapat menghindar dari fagositosis makrofag peritoneum (Hariyanti et. al., 2015). Setelah diinjeksikan dengan suspensi bakteri, seluruh kelompok perlakuan didiamkan selama 1 jam. Hal ini bertujuan untuk membuat sistem non spesifik dapat bekerja, karena sistem imun non spesifik dapat bekerja sekitar 0-12 jam setelah infeksi terjadi (Abbas et al., 2007). Makrofag dan neutrofil, termasuk ke dalam pertahanan di lini pertama dalam sistem imunitas. Walaupun biasanya tidak berada dalam jumlah cukup untuk menghadapi serangan bakteri. Makrofag mampu menahan infeksi selama periode sekitar 1 jam pertama sebelum mekanisme imunitas lain dapat dimobilisasi. Atas dasar inilah maka pengambilan makrofag dilakukan sekitar 1 jam setelah induksi bakteri, sehingga akan diketahui sejauh mana kemampuan makrofag dalam mengatasi invasi bakteri (Sriningsih \& Wibawa, 2006).

Setelah didiamkan selama 1 jam, Kemudian dilakukan pembedahan pada seluruh kelompok hewan uji. Jika ditemukan cairan peritoneum mencit dalam keadaan sedikit maka di tambahkan larutan PBS ke dalam selubung peritoneum mencit, pemberian ini bertujuan untuk membantu melarutkan sel-sel makrofag yang melekat pada organ mencit, sehingga mempermudah dalam pengambilan cairan peritoneum mencit. Setelah cairan peritoneum diperoleh kemudian dibuat apusan tipis dan diamati dibawah mikroskip cahaya dengan perbesaran 1000x. Perbedaan antara makrofag aktif dan tidak aktif dapat dilihat pada gambar 1 . 


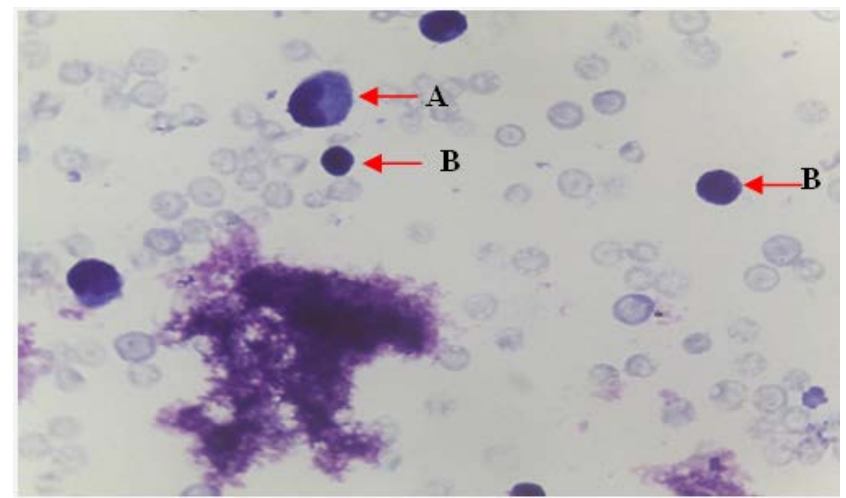

Gambar.1 Makrofag aktif dan tidak aktif (A) Makrofag aktif, (B) Makrofag tidak aktif
Makrofag aktif ditandai dengan bentuk dan ukuran makrofag yang bertambah besar dengan penjuluran pseudopodi yang sangat bervariasi. Fagosomnya muncul membran yang menjadi lebih berliku-liku, lisosom menjadi lebih banyak, aparat golgi membesar dan retikulum endoplasma kasar berkembang (Bratawidjaja \& Rengganis, 2014).

Pengujian imunomodulator dilakukan dengan menghitung nilai aktivitas fagositosis makrofag peritoneum mencit. Nilai aktivitas fagositosis dapat dihitung dari makrofag yang aktif melakukan fagositosis diantara 100 jumlah sel yang dinyatakan dalam bentuk persen dan dapat dilhat pada tabel 3 dan gambar grafik 2 .

Tabel 3. Hasil Aktivitas Fagositosis Makrofag Aktif

\begin{tabular}{|c|c|c|c|c|c|}
\hline \multirow[b]{2}{*}{ Kelompok/perlakuan } & \multicolumn{4}{|c|}{ Jumlah sel yang teraktivasi (\%) } & \multirow[b]{2}{*}{ Rata-Rata (\%) } \\
\hline & 1 & 2 & 3 & 4 & \\
\hline Kelompok I (Dosis 100 mg/kgBB) & 33 & 36 & 29 & 39 & 34,25 \\
\hline Kelompok II (Dosis 200 mg/kgBB) & 44 & 47 & 43 & 54 & 47,00 \\
\hline Kelompok III (Dosis 300 mg/kgBB) & 57 & 60 & 62 & 59 & 59,50 \\
\hline Kelompok IV (Dosis 400 mg/kgBB) & 59 & 62 & 67 & 63 & 62,75 \\
\hline Kontrol Negatif (Na-CMC 0,5\%) & 24 & 23 & 25 & 25 & 24,25 \\
\hline Kontrol Positif (Stimuno ${ }^{\circledR} 0,13$ mg/gBB) & 60 & 66 & 67 & 61 & 63,50 \\
\hline
\end{tabular}

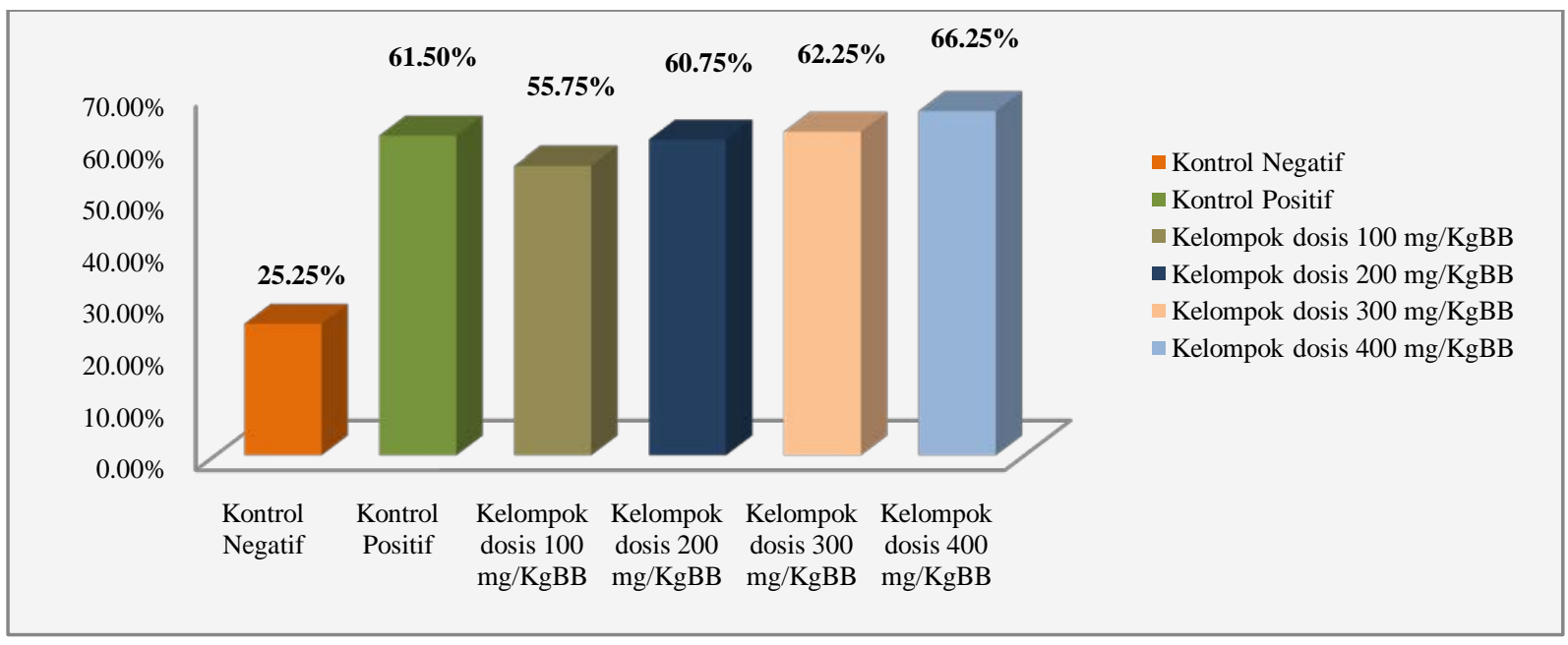

Gambar 2 Grafik Peningkatan Aktifitas Fagositosis Makrofag 
Berdasarkan hasil yang ditampilkan pada tabel 3 dan gambar grafik 2 dapat diketahui bahwa aktivitas fagositosis makrofag berbanding lurus dengan peningkatan dosis sediaan. Aktivitas fagositosis semakin meningkat seiring dengan peningkatan dosis sediaan. Peningkatan persen aktivitas fagositosis sel makrofag yang tertinggi terdapat pada kelompok dosis dosis $400 \mathrm{mg} / \mathrm{kgBB}$ yaitu sebesar 66,25\% yang lebih tinggi dari kelompok kontrol positif sebesar 61,50\%, dan kelompok dosis $100 \mathrm{mg} / \mathrm{kgBB}, 200$ $\mathrm{mg} / \mathrm{kgBB}$, dan $300 \mathrm{mg} / \mathrm{kgBB}$ yang secara berturutturut memiliki persen aktivitas fagositosis sebesar 55,75\%, 60,75\%, dan 62,25\%. Sedangkan persen aktivasi fagositosis yang terdendah terdapat pada kelompok kontrol negatif yaitu, 25,25\%.

Pemberian infeksi bakteri Staphylococcus aureus pada penelitian ini memicu terjadinya infeksi pada mencit. Pada saat terjadi proses infeksi, limfosit $\mathrm{T}$ akan menghasilkan sejumlah limfokin yang menarik makrofag ke tempat yang membutuhkan dan mengaktifkannya. Makrofag yang aktif akan mengeluarkan beberapa substansi penting yaitu: enzim-enzim, lisozim, elastase, kolagenase, komplemen dan sitokin (Efendi, 2003). Sitokin yang disekresikan makrofag antara lain; Interleukin (IL)-1, IL-6, IL-8, IL-12, IL-15 dan TNF $\alpha$ (Lestarini, 2008). Pada keadaan normal proses tersebut berlangsung lambat sehingga jumlah sel makrofag yang aktif melakukan proses fagositosis juga sedikit (Wahidah, 2010). Adanya peningkatan aktivitas fagositosis sel makrofag pada mencit jantan menandakan bahwa pada ekstrak etanol spons Melophlus sarasinorum terdapat senyawa kimia yang dapat meningkatkan aktivitas fagositosis makrofag (imunostimulan).

Hasil uji skrining fitokimia spons Melophlus sarasinorum menunjukan adanya kandungan senyawa flavonoid. Senyawa flavanoid dapat bekerja terhadap limfokin (Interferon $\gamma$ ) yang dihasilkan oleh sel $\mathrm{T}$ sehingga akan merangsang sel-sel fagosit melakukan respon fagositosis serta dapat memacu proliferasi limfosit, meningkatkan jumlah sel $\mathrm{T}$, dan meningkatkan sekresi terhadap Interleukin-2 (Asep, et, al., 2014). Hasil ini didukung oleh penelitian yang dilakukan Yusuf et al., 2019 dimana ekstrak tumbuhan galing meningkatkan aktivitas fagosistosis sel makrofag mencit Balb/C secara signifikan, dimana tumbuhan galing mengandung senyawa flavanoid yang diduga memiliki sifat imunostimulan dengan memicu prolifersai sel makrofag dan limfosit. Peningkatan jumlah sel limfosit $\mathrm{T}$ dapat memicu peningkatan aktivitasi makrofag sehingga akan memicu peningkatan sekresi sitokin seperti IL-1, IL6, IL-12 dan TNF alpha yang dapat meningkatkan fagositosis bakteri oleh makrofag (Abbas et al., 2007).

Penelitian sebelumnya telah terbukti bahwa flavonoid meningkatkan aktivasi sel efektor seperti limfosit, makrofag yang memproduksi dan melepaskan sitokin, interleukin IL-1; IL-6; IL-12; tumor nekrosis faktor alpha (TNF alpha). Dosis flavonoid yang lebih tinggi membuat sel leukosit (fagosit) lebih aktif terhadap sel bakteri fagosit, dan lebih banyak bakteri yang dapat dirusak dan dicernaan dengan sel leukosit (Zalizar, 2013). Senyawa tanin yang juga terkandung pada spons Melophlus sarasinorum juga dapat mempengaruhi aktivitas fisiologi manusia seperti menstimulasi sel-sel fagosit antitumor, dan antibakteri (Haslam,1996).

Data aktivitas fagositosis yang telah diperoleh dari masing-masing kelompok kemudian dilakukan pengujian statistik menggunakan SPSS (Statistical Package For Social Science) dengan metode ANOVA satu arah untuk mengetahui ada tidaknya perbedaan pemberian ekstrak etanol spons Melophlus sarasinorum pada berbagai dosis terhadap aktivitas fagositosis sel makrofag. Sebelum dilakukan pengujian ANOVA terlebih dahulu harus dilakukan pengujian normalitas dan uji homogenitas. Uji normalitas bertujuan untuk mengetahui apakah data terdistribusi normal (sig > 0,05) atau tidak (sig < 0,05). Berdasarkan hasil uji normalitas diketahui bahwa data memiliki nilai sig sebesar 0,748. Maka dapat dinyatakan bahwa data telah terdistribusi normal. Sedangkan uji homogenitas bertujuan untuk menentukan apakah dari beberapa kelompok perlakuan memiliki varian yang sama (sig > 0,05) atau tidak (sig < 0,05). Berdasarkan hasil uji homogenitas diketahui bahwa data memiliki nilai sig sebesar 0,480. Sehingga dapat dikatakan bahwa data memiliki variasi yang sama/homogen. Setelah uji distribusi normal dan homogenitas dilakukan, didapatkan nilai signifikansi $(\mathrm{p}>0,05)$ yang berarti bahwa himpunan data yang dimiliki memiliki karakteristik yang sama (homogen) dan terdistribusi normal, sehingga dapat dilanjutkan pada pengujian ANOVA.

Pengujian ANOVA yang dilakukan bertujuan untuk melihat adanya perbedaan dari empat variasi dosis pemberian ekstrak etanol spons Melophlus 
sarasinorum terhadap peningkatan aktivitas fagositosis makrofag. Berdasarkan hasil uji ANOVA satu arah diketahui bahwa data memiliki nilai sig. < 0,05 yakni sig. 0,000 yang berarti bahwa hipotesis $\mathrm{H}_{0}$ (tidak terdapat perbedaan) ditolak dan hipotesis $\mathrm{H}_{1}$ (terdapat perbedaan) diterima. Untuk melihat pemberian ekstrak dosis $100 \mathrm{mg} / \mathrm{kgBB}, 200$ $\mathrm{mg} / \mathrm{kgBB}, 300 \mathrm{mg} / \mathrm{kgBB}, 400 \mathrm{mg} / \mathrm{kgBB}$ efektif dalam meningkatan aktivitas fagositosis makrofag maka analisis statistik dilanjutkan dengan analisis BNT dengan metode tukey tabel 4.

Tabel 4. Hasil Uji Post Tukey Aktivitas Fagositosis Sel Makrofag

\begin{tabular}{|c|c|c|c|}
\hline Perlakuan & $\begin{array}{c}\text { Dibandingkan } \\
\text { dengan } \\
\text { kelompok } \\
\text { perlakuan }\end{array}$ & $\begin{array}{c}\text { Nilai } \\
\mathbf{p}\end{array}$ & Makna \\
\hline \multirow{5}{*}{$\begin{array}{l}\text { Kontrol } \\
\text { Negatif }\end{array}$} & Kontrol Positif & ,000* & $\begin{array}{c}\text { Ada } \\
\text { Perbedaan }\end{array}$ \\
\hline & $\begin{array}{l}\text { Dosis } 100 \\
\mathrm{mg} / \mathrm{kgBB}\end{array}$ & ,000* & $\begin{array}{c}\text { Ada } \\
\text { Perbedaan }\end{array}$ \\
\hline & $\begin{array}{l}\text { Dosis } 200 \\
\mathrm{mg} / \mathrm{kgBB}\end{array}$ & ,000* & $\begin{array}{c}\text { Ada } \\
\text { Perbedaan }\end{array}$ \\
\hline & $\begin{array}{l}\text { Dosis } 300 \\
\mathrm{mg} / \mathrm{kgBB}\end{array}$ &, $000 *$ & $\begin{array}{c}\text { Ada } \\
\text { Perbedaan }\end{array}$ \\
\hline & $\begin{array}{l}\text { Dosis } 400 \\
\mathrm{mg} / \mathrm{kgBB}\end{array}$ &, $000 *$ & $\begin{array}{c}\text { Ada } \\
\text { Perbedaan }\end{array}$ \\
\hline \multirow{5}{*}{$\begin{array}{l}\text { Kontrol } \\
\text { Positif }\end{array}$} & Kontrol Negatif & ,000* & $\begin{array}{c}\text { Ada } \\
\text { Perbedaan }\end{array}$ \\
\hline & $\begin{array}{l}\text { Dosis } 100 \\
\mathrm{mg} / \mathrm{kgBB}\end{array}$ & ,022* & $\begin{array}{c}\text { Ada } \\
\text { Perbedaan }\end{array}$ \\
\hline & $\begin{array}{l}\text { Dosis } 200 \\
\mathrm{mg} / \mathrm{kgBB}\end{array}$ & ,977 & $\begin{array}{l}\text { Tidak Ada } \\
\text { Perbedaan }\end{array}$ \\
\hline & $\begin{array}{l}\text { Dosis } 300 \\
\mathrm{mg} / \mathrm{kgBB}\end{array}$ & 1,000 & $\begin{array}{l}\text { Tidak Ada } \\
\text { Perbedaan }\end{array}$ \\
\hline & $\begin{array}{l}\text { Dosis } 400 \\
\mathrm{mg} / \mathrm{kgBB}\end{array}$ & 196 & $\begin{array}{l}\text { Tidak Ada } \\
\text { Perbedaan }\end{array}$ \\
\hline
\end{tabular}

Keterangan : Nilai p adalah Signifikansi, Nilai p $>0,05$ artinya tidak ada perbedaan bermakna, Nilai $\mathrm{p}$ $<0,05$ artinya ada perbedaan bermakna

Uji post hoc Tukey dilakukan sebagai lanjutan dari uji ANOVA pada masing-masing kelompok perlakuan. Tujuan uji post hoc Tukey untuk melihat kelompok perlakuan mana yang memiliki efek yang sama atau berbeda signifikan antara satu dengan yang lain sehingga diperoleh susunan kelompok yang berbeda. Data hasil uji post hoc Tukey tabel 4, menunjukkan bahwa pada dosis $200 \mathrm{mg} / \mathrm{KgBB}, 300$ $\mathrm{mg} / \mathrm{KgBB}$ dan $400 \mathrm{mg} / \mathrm{KgBB}$ tidak berbeda signifikan dengan kelompok kontrol positif dengan nilai Sig masing-masing $>0.05$ yaitu 0,$977 ; 0,1000$; dan 0,196 yang artinya pada dosis $200 \mathrm{mg} / \mathrm{KgBB}$, $300 \mathrm{mg} / \mathrm{KgBB}$ dan $400 \mathrm{mg} / \mathrm{KgBB}$ memiliki aktivitas yang tidak berbeda nyata dengan kontrol positif. Namun pada dosis $400 \mathrm{mg} / \mathrm{kgBB}$ menunjukan peningkatan aktivitas yang lebih baik dibanding dengan dosis $300 \mathrm{mg} / \mathrm{kgBB}$.

\section{KESIMPULAN}

1. Kandungan metabolit sekunder yang terdapat dalam ekstrak etanol spons Melophlus sarasinorum adalah alkaloid, flavonoid, saponin dan tannin.

2. Ekstrak etanol spons Melophlus sarasinorum memiliki efek sebagai imunomodulator dengan meningkatkan aktivitas fagositosis sel makrofag pada mencit jantan.

3. Dosis ekstrak etanol spons Melophlus sarasinorum yang efektif sebagai imunomodulator terdapat pada dosis $200 \mathrm{mg} / \mathrm{Kg}$ BB, 300 mg/Kg BB dan 400 mg/Kg BB.

\section{DAFTAR PUSTAKA}

Abbas, A. K., Lichtman, A. H., \& Pillai, S. (2017). Cellular and molecular immunology-9th ed. Elsevier

Akrom, A., Widjaya, A., \& Armansyah, T. (2015). Ekstrak Etanol Biji Jintan Hitam (Nigella Sativa) Meningkatkan Aktivitas Fagositosis Makrofag Mencit Swiss Yang Diinfeksi Lysteria monocytogenes. Jurnal Kedokteran Hewan, 9(2):94-100.

Aldi, Y., Rasyadi, Y., \& Handayani, D. (2015). Aktivitas Imunomodulator dari Ekstrak Etanol Meniran (Phyllanthus niruri Linn.) terhadap Ayam Broiler. Jurnal Sains Farmasi \& Klinis, 1(1), 20-26.

Angelina, M., Amelia, P., Irsyad, M., Meilawati, L., \& Hanafi, M. (2015). Karakterisasi Ekstrak Etanol Herba Katumpangan Air (Peperomia Pellucida L. Kunth). Biopropal Industri, 6(2), 53-61.

Aspinall, R. (2005). Ageing and the immune system in vivo: Commentary on the 16th session of British Society for Immunology Annual Congress, Harrogate, December 2004. Immunity \& Ageing, 2(1), 5. https://doi.org/10.1186/1742-4933-2-5 
Bratawidjaja. K. G., Rengganis. I. (2014) Imunologi Dasar. Jakarta: Badan Penerbit Fakultas Ilmu Kedokteran Universitas Indonesia.

Christina, B.B.H., Cindy, F., Keshia, K., Caroline, Janti, S. (2015). Peran Monosit (Makrofag) Pada Proses Angiogenesis Dan Fibrosis. Seminar Nasional Cendekiawan. ISSN: 24608696.

Departemen Kesehatan Republik Indonesia. (2000). Parameter Standar Umum Ekstrak Tumbuhan Obat. Jilid VI. Jakarta: Direkterot Jendral POM-Depkes RI.

Direktorat Jendral POM. (2008). Farmakope Herbal Indonesia Edisi 1, Jakarta: Departemen Kesehatan Republik Indonesia.

Febriana. M. V. (2015). Pengaruh Meniran (Phyllanthus niruri Linn) Terhadap Gambaran Histopatologi Hepar Tikus Putih (Rattus Norvegicus) Jantan Yang Diinduksi Obat Anti Tuberkulosis (Rifampisin Dan Isoniazid). Skripsi fakultas kedokteran universitas Airlangga. Surabaya

Hardianti. A. (2018). Uji Efektivitas Antihiperlipidemia Ekstrak Etanol Spons Melophlus Sarasinorum Terhadap Tikus Jantan Galur Wistar. Skripsi Universitas Halu Oleo. Kendari

Hariyanti, Sunaryo, H., \& Nurlaily, S. (2015). Efek Imunomodulator Fraksi Etanol Dari Ekstrak Etanol 70 \% Kulit Buah Manggis (Garcinia Mangostona L.) Berdasarkan Peningkatan Aktivtas Dan Kapasitas Fagositpsis Makrofag Peritoneum Mencit Secara In Vitro. Jurnal Pharmacy, 12(1), 58-69.

Isnawati, A., Alegentina, S., Widowati, L. (2013) Karakterisasi Ekstrak Etanol Biji Klabet (Trigonella foenum-graecum L) Sebagai Tanaman Obat Pelancar Asi, Buletin Penelitian Kesehatan, 41(2):103-110.

Katzung, B. G., Trevor, A. J., \& Masters, S. B. (1995). Basic \& Clinical Pharmacology 6 th Ed. New York: Lange Medical Books/McGraw-Hill, Medical Pub. Division.
Kresno, S.B. (1996). Irnunologi: Diagnosis dan Prosedur Laboratorium, Ed. Ill. Jakarta: Fakultas Kedokteran Universitas Indonesia.

Kurnianingtyas, E., Djati, M. S., \& Rifa'i, M. (2013). Aktivitas Imunomodulator Polyscias obtusa Terhadap Sistem Imunitas Pada Bone Marrow Broiler Setelah Pemberian Salmonella typhimurium. The Journal of Experimental Life Sciences, 3(1), 25-30.

Pangestika, D., Mirani, E., \& Mashoedi, I. D. (2012). Pengaruh Pemberian Kunyit (Curcuma domestica Val.) terhadap Aktivitas Fagositosis Makrofag psada Mencit BALB/C yang Diinokulasi Bakteri Listeria monocytogenes. Jurnal Internasional, 4(1), 63-70.

Reha, W., Noor, A., Ahmad, A., Nafie, N. la, \& Salama Damma. (2013). Karakterisasi Protein Aktif Dari Spons Dan Mikroba Simbionnya Sebagai Usaha Awal Menuju Agen Imunostimulan. Marina Cimica Acta, 14(1), 40-49.

Soekamto, N. H., Nafie, N. L., Permatasari, N. U., \& Zenta. (2013). Studi Pendahuluan Bioaktivitas dan Identifikasi Kelompok Metabolit Sekunder Pada Spons Melophlus Sarasinorum Thiele Asal Pulau Kapoposang, Spermonde. HKI Cabang Sumatra Barat.

Sriningsih., Wibawa. A.E. (2006). Efek protektif pemberian ekstrak etanol herba meniran (Phyllantus niruri L) terhadap aktivitas dan kapasitas fagositosis makrofag peritonium tikus. Artocarpus, 6:91-96.

Sudarmadji. S., (1989). Analisis Untuk Bahan Makanan dan Pertanian. Yogyakarta: Liberty.

Wahidah. N. (2010), Efektivitas Suplementasi Mikromineral Seng (Zn) Terhadap Indeks Fagositosis Makrofag Mencit Balb/C Yang Diinfeksi Salmonella typhimurium. Skripsi, Fakultas Matematika dan Ilmu Pengetahuan Alam, Universitas Negeri Semarang

Winarno. F.G. (1992). Kimia Pangan dan Gizi. Jakarta: PT. Gramedia Pustaka Utama.

Yusuf, M. I., Firdayanti, \& Wahyuni. (2019). Peningkatan Imunitas Non Spesifik (Innate Immunity) Mencit Balb/C Yang Diberi Ekstrak 
Etanol Daun Tumbuhan Galing (Cayratia trifolia L. Domin). Jurnal Medical Sains, 3(2), 83-92.

Zalizar, L. (2013). Flavonoids of Phyllanthus Niruri as Immunomodulators.A Prospect to Animal Disease Control. ARPN Journal of Science and Technology. 3(5):529-532 